[In spring 2007, then co-editor Iris Smith Fischer solicited comments and reflections on the Journal's first twenty years from current and former associate, managing, and section editors. What follows is a collection of contributions received, from associate editors Herbert Blau, Michal Kobialka, and Patricia Ybarra; former "Praxis" editor Kent Neely; former managing editor Joy Richmond; and contributor Les Essif. Unlike Henry Bial's interview with John Gronbeck-Tedesco, the forum is, in a sense, virtual; only with this issue's publication will the authors read each other's comments. The dialogue, perhaps fittingly, takes place in the reading of it.]

\title{
Inescapable Mimesis: JDTC in the Mortal Coil
}

\section{Herbert Blau}

As a long-time Associate Editor, I was somewhat delinquent in not noticing, on the journal's back cover in those earlier days, its promising agenda or governing prospect, that it would be filling "a long-term need for a publication which addresses the theoretical issues associated with performance and performance texts." Otherwise, I might have wondered sooner why the title has remained what it is, Journal of Dramatic Theory and Criticism, even when Theory, in the age of deconstruction, slipped past the conjunction, subsuming Criticism, or as a "textual event" itself, dwelling on absence, putting it "under erasure." As for the Dramatic, so far as it assumed a text (that is, "dramatic literature") and a dubious idea of theatre, it was with ideological vigilance subjected to critique (not quite the same as criticism) and supplanted by Performance. About the time that theatre was spilling into the streets, and everything was seen as performance - everyday life, corporate life, ritual, fashion, sex, science, from spacing out to outer space, and in a world of simulacra, the "liveness" of virtuality - theory itself had, through the wordplay of différance, its metonymic shifts, became performative too.

With performance art and body art, there was also the "textual body," and with that inscripted body an escape from the "tyranny of meaning" into the polymorphous repertoire of hallucinatory soundings, theorized by Roland Barthes as "the 'grain' of the voice." As for the conceptual substance, it was from Derridean grammatology to Deleuzian desiring-machines (and through it all, the spectre of Marx) distrustful of mimesis and the hegemony of bourgeois power, once framed by the proscenium, in the vice of representation. Much of this was concurrent with the anthropological/ethnological dispensation that (sponsored by

Herbert Blau is Byron W. and Alice L. Lockwood Professor of the Humanities at the University of Washington. 
$T D R$ ), led to Performance Studies, though such programs were not, to begin with, really theoretical. (Indeed, many years ago I was invited by Richard Schechner to introduce, against his own disposition, what is now canonical theory in a graduate seminar at NYU, where most of the faculty were unfamiliar not only with Lacan's Freud, and poststructuralism, but Adorno and Benjamin too). As for my own more ontological view of theatre, itself a shadow of theory, that developed through years of rehearsal, and a method of "ghosting" there: the materialization of theatre from whatever it is it is not. Whatever it is, however, there remains this undeniable fact: whoever is there performing is dying in front of your eyes. And the theatre smells of mortality, even when nobody's on stage. Since I've written much of all this, with fallout in JDTC, I won't belabor it here.

But since the Dramatic is, with Theory, caught up in the mortal coil, let me back up to that, and the charges against mimesis, which from whatever beginning has been on trial in the theatre. For all the corrosive critique, no less claims of abolition, the mimetic is obdurate, as if engrailed in theatre, not as social or historical construction but an aspect of history itself, stained as it is with mortality. And the stain is there regardless, even in a shadow play, no difference with cultural difference - the Noh, Kathakali, Hada, the forms from other cultures, including now Zooësis, the culture of animals. As for the mimetic element in artistic forms, however you look at it, so long as you look, it is easier regaled against than removed, whatever we see seen, through whatever sensation or culture, as resembling what we know from experience, the enactment of meaning there.

Aesthetically and theoretically, there have been forms of resistance. Back when deconstruction appeared on the American scene, Paul de Man argued that irony-his concept of which was derived from a semiotic understanding of irony in early Romanticism - "steadily undermines this claim at imitation and substitutes for it a conscious, interpreted awareness of the distance that separates an actual experience from the understanding of this experience."2 It may be impossible, logically, to conceive of art as mimetic discourse, but it is precisely the impossible which returns like the repressed. So with dramatic form as it moves from page to stage, there submitted to specularity, and - offstage onstage-subjectivity in the theatre, defying Alienation, that "interpreted awareness of the distance that separates. .." And I'm very conscious of this now, in writing an autobiography, across the distance of half a century from my having directed the first production in America of Brecht's Mother Courage, and not long after, Galileo, where even the Copernican system was translated by the mimetic, and the moons of Jupiter too, across the distance that separates.

We have seen over the years - from Wilson and Foreman to the Wooster Group, and other theatre work - a struggle to overcome (or the illusion of it) what has been thought of in critical theory as the idealist notion of the independent subject or self-identical agent. But as in a blur of abstraction, like the abolition of the figure 
in the action painting of Pollock, something more than a shadow of that agent reappears. Through the entire history of the avant-garde - and all the experiments with ruptured form, fragmentation, dispersion of the subject-it is realism and mimesis which take the measure of the manifestation, whatever it is that shows in the discontinuous or subverted structures of the forms that remain. That, to be sure, is the unromantic irony. Attached as it appears to be to the irrepressible real-what merely appears but cannot be constructed - there is in the order of things the threat of reproduction, which indeed, as Foucault saw in the cycles of power, reproduces itself, though no alarm system has protected us from it.

So it is, too, with the vice of representation, which Derrida had to concede at the forlorn end of his essay on Artaud, "The Theatre of Cruelty and the Closure of Representation"-which, to think at all, "is to think the tragic: not as the representation of fate, but as the fate of representation. Its gratuitous and baseless necessity." Baseless it may be, but "it is to think why it is fatal that, in its closure, representation continues." And thus, too, with the mimetic, unpurgeable in performance, wherever it may be, which may be a justification for keeping Dramatic in the journal's title, while Theory continues to struggle, at its own critical edge, with why it should be.

\section{Notes}

1. Roland Barthes, "The Grain of the Voice," in Image-Music-Text, trans. Stephen Heath (New York: Hill \& Wang, 1977) 185.

2. Paul de Man, "Georg Lukác's Theory of the Novel," in Blindness and Insight: Essays in the Rhetoric of Contemporary Criticism, intro. Wlad Godzich (Minneapolis: U of Minnesota P, 1983) 56. Notice that de Man - who gave Barthes a hard time at Johns Hopkins, at the first big theory conference here, and then discredited theory, with revelations of his favorable writings about the Nazis-uses the word Criticism in his title.

3. Jacques Derrida, Writing and Difference, trans. and intro. Alan Bass (Chicago: U of Chicago P, 1978) 250 . 